\title{
Avoidance Responses of Fathead Minnow to Strikes by Four Teleost Predators
}

\author{
P.W. Webb \\ The University of Michigan, School of Natural Resources, Ann Arbor, Michigan 48109, USA
}

Accepted February 19, 1982

Summary. 1. Predator avoidance behavior of fathead minnow (Pimephales promelas) attacked by four teleosts (tiger musky, Esox sp; rainbow trout, Salmo gairdneri; smallmouth bass, Micropterus dolomieu; rock bass, Ambloplites rupestris) was analyzed using stop-action video-tape recordings of predator-prey in-. teractions. The predators represented a range of body forms.

2. 75 to $90 \%$ of minnows responded to strikes by trout, bass and rock bass, but only $28 \%$ responded to strikes by tiger musky. Responses were 54 to $94 \%$ successful in evading a strike.

3. Two prey avoidance response patterns were found. Type-1 responses were low intensity, non-sustained turning maneuvers away from more distant and more slowly moving predators. Type- 2 responses were high intensity turning maneuvers followed by sustained swimming away from closer and fastermoving predators. All responses to tiger musky were type-2 responses. Prey speeds in avoidance responses were lower for rock bass than for the other three predators.

4. Response thresholds for fathead minnow escape maneuvers were calculated at the start of the motor response, and evaluated with respect to predator size. Predator size was calculated from the dimensions of the silhouette viewed by the prey as the mean of predator depth and width. Prey reaction distance decreased and predator visual angle increased with predator size for trout, bass and rock bass. Reaction distance was smaller, and visual angle larger for responses to tiger musky.

5. The rates of change of the visual angle at the start of a response, the apparent looming threshold

Abbreviations: $A L T$ used throughout the text is the apparent looming threshold for prey avoidance responses to a predator strike. ALT is defined as the rate of change of the angle subtended by the approaching predator viewed by the prey as calculated at the beginning of the prey's avoidance motor response
(ALT), were similar for trout, bass and rock bass, but 15-80 times larger for tiger musky.

6. The results suggest that configuration differences between the predators are important contributors to the stimulus initiating avoidance responses. It is suggested that the rounded body cross-section of esocids is associated with higher response thresholds than elliptical and lenticular cross-sections of trout, bass and rock bass.

\section{Introduction}

The effectiveness of piscivorous fish in catching their prey varies among species. For example, esocids may catch up to $70 \%$ of prey attacked (Webb and Skadsen 1980) whereas carangids are only about $15 \%$ successful (Major 1978). The behavior of piscivores is, of course, variable among species, but in all situations, predator-prey interactions converge on a final strike determining catch success. Strike success itself depends on a combination of minimizing flight responses and closure times between the predator and prey.

It would be attractive to attribute variable success of piscivores to relative locomotor performance among different species. However, measures of performance of esocids and bass attacking prey show that closure times are similar over a large range of distances, $\leqq 100 \mathrm{~cm}$. For example, $23 \mathrm{~cm}$ long tiger musky (Esox) would close with prey $1 \mathrm{~cm}$ distant in 11 ms while large-mouth bass (Micropterus salmoides) of the same size would take $14 \mathrm{~ms}$. For a $10 \mathrm{~cm}$ strike, these times are 159 and $143 \mathrm{~ms}$ respectively (Nyberg 1971; Webb and Skadsen 1980). Nevertheless, limited observations suggest Esox may be more effective than other fish piscivores in reaching their prey before the 


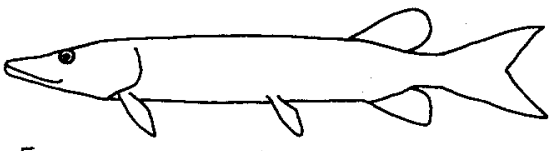

Esox

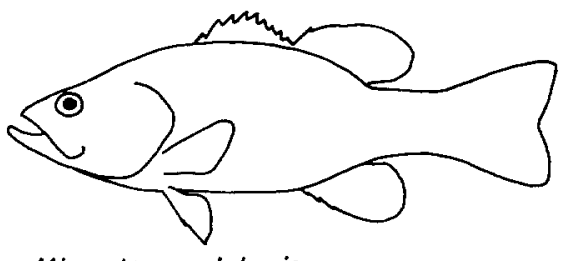

Micropterus dolomieu
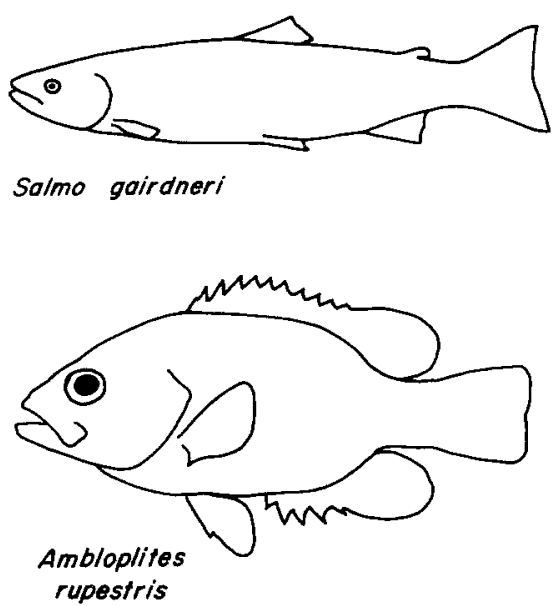

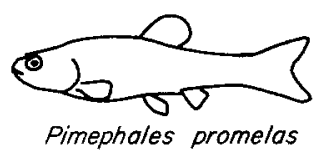

Fig. 1. The four species of teleost predators, and the fathead minnow prey

Table 1. Morphological characteristics of the four teleost predators used in observations of escape responses by fathead minnow. The mean of depth and width includes extended pectoral fins where pectoral propulsion was used by striking predators. Data are shown as $\bar{X} \pm 2 \mathrm{SE}$

\begin{tabular}{lllllll}
\hline Species & $\begin{array}{l}\text { Total } \\
\text { length } \\
\mathrm{cm}\end{array}$ & $\begin{array}{l}\text { Mass } \\
\mathrm{g}\end{array}$ & $\begin{array}{l}\text { Maximum } \\
\text { depth } \\
\mathrm{cm}\end{array}$ & $\begin{array}{l}\text { Maximum } \\
\text { width } \\
\mathrm{cm}\end{array}$ & $\begin{array}{l}\text { Mean depth } \\
\text { and width } \\
\mathrm{cm}\end{array}$ & $\begin{array}{l}\text { Distance } \\
\text { of maximum } \\
\text { depth and width } \\
\text { from nose } \\
\mathrm{cm}\end{array}$ \\
\hline $\begin{array}{l}\text { Esox } \\
\text { (tiger musky) }\end{array}$ & $23.6 \pm 1.0$ & $51.09 \pm 6.94$ & $2.5 \pm 0.3$ & $2.5 \pm 0.3$ & $2.5 \pm 0.3$ & $10.0 \pm 0.5$ \\
$\begin{array}{l}\text { Salmo gairdneri } \\
\text { (rainbow trout) }\end{array}$ & $25.0 \pm 1.8$ & $165.02 \pm 20.24$ & $5.0 \pm 0.3$ & $2.6 \pm 0.3$ & $3.8 \pm 0.4$ & $9.5 \pm 0.9$ \\
$\begin{array}{l}\text { Micropterus dolomieu } \\
\text { (smallmouth bass) }\end{array}$ & $23.6 \pm 1.4$ & $184.53 \pm 30.00$ & $5.3 \pm 0.6$ & $2.7 \pm 0.2$ & $4.0 \pm 0.5$ & 20 \\
$\begin{array}{l}\text { Ambloplites rupestris } \\
\text { (rock bass) }\end{array}$ & $15.1 \pm 1.9$ & $61.92 \pm 23.08$ & $6.2 \pm 0.8$ & $2.4 \pm 0.2$ & $5.2 \pm 0.7$ & $5.6 \pm 0.3$ \\
\hline
\end{tabular}

prey responds (Webb and Skadsen 1980) implying variable response thresholds for different predators.

Therefore the present research examined avoidance responses of a typical forage fish during attacks by several different predators. The objective was to determine if response differences did occur, and to evaluate possible mechanisms for any observed variations.

\section{Materials and Methods}

Prey Species. The prey species, fathead minnow (Pimephales promelas), was obtained from local bait stores. Only healthy individuals were used for experiments after acclimation to laboratory condi- tions. The mean length and mass of minnows used were $5.5 \pm 0.2$ $\mathrm{cm}$ and $1.02 \pm 0.14 \mathrm{gm}(\bar{X} \pm 2 \mathrm{SE} ; n=50)$, respectively, as determined from sub-samples.

Predator Species. The four predator species used were tiger musky (Esox sp; male Esox lucius $\times$ female Esox masquinongy), rainbow trout (Salmo gairdneri), smallmouth bass (Micropterus dolomieu) and rock bass (Ambloplites rupestris). They are illustrated in Fig. 1.

Physical characteristics for the predators are shown in Table 1. In addition to standard measurements, the size of the fish pertinent to predation situation was required. Size was measured in terms of the predator's maximum body cross-section as the mean of the maximum depth and width. This measure was used because the cross-sectional shape will dominate the silhouette of a predator moving along its long axis towards the prey. Width was measured from video records (see below) to include the pectoral fins when they were extended at the instant of a prey response. 
The form and locomotor repertoire varied among the four predators. Tiger musky have elongate bodies with uniform depth over much of the body length, and a more or less circular crosssectional shape. The other three species vary in depth along the body length. Depth variation is moderate in trout and bass (fusiform bodies) and larger in rock bass (gibbose bodies). These three species are laterally flattened.

Caudal area is enhanced in all four species by the posterior location of the anal fins, the posterior location of the dorsal fin in tiger musky, and posterior extension of the dorsal fins in bass and rock bass. These features enhance acceleration (Weihs 1972, 1973; Webb 1977). Total depth is augmented over the center of mass by the dorsal fin in trout, bass and rock bass which would reduce recoil from propulsive movements. Bass and rock bass have well developed pectoral fins inserted high on the body for efficient non-caudal slow swimming (Webb 1982 b).

Musky, trout and bass were obtained from fish hatcheries and rock bass were seined from local streams. All the fish were acclimated to the laboratory before experiments. They were fed on live fathead minnows so that all would be similarily experienced in attacking the prey. Individual predators were starved for one week before use in experiments to ensure uniform high feeding motivation.

Procedures. Predator-prey strike interactions were observed in a glass-bottomed arena $50 \mathrm{~cm}$ square and $10 \mathrm{~cm}$ deep, delineated within a larger tank $120 \mathrm{~cm}$ long, $60 \mathrm{~cm}$ wide and $30 \mathrm{~cm}$ deep by plastic grid $(1.25 \mathrm{~cm})$ lined with screen $(0.3 \mathrm{~cm}$ mesh). The arena was covered by a translucent lid illuminated by two standard $40 \mathrm{~W}$ fluorescent lights. The dimensions of the arena were more than sufficient to accurately record behavior during a strike, the focus of these experiments, but excluded evaluation of predator orientation behavior and most chases (Webb and Skadsen 1980). Chases were rare, except for trout.

Individual predators were starved for two days and placed in the arena one day before an experiment. Single prey were introduced through one of four $2.5 \mathrm{~cm}$ diameter side ports via waterfilled cups. This procedure minimizes stress and does not impair prey performance. As each prey fish was eaten, additional prey were introduced until the predator refused to eat. All tests were performed at $15^{\circ} \mathrm{C}$, the same as the acclimation temperature.

Interactions were recorded on video tape via a $45^{\circ}$ mirror located beneath the arena. Tape was advanced by hand to analyze events to within $1 / 60 \mathrm{~s}$. Locomotor patterns of prey and predators were recorded before, during and after a strike. The proportion of prey avoidance responses and their effectiveness in eluding strikes were recorded. The initial speed and turning angle of the avoidance maneuver were measured as indicators of response intensity. The distance separating the predator and prey (prey reaction distance) and predator and prey speeds were measured at the time of the prey response. The visual angle subtended by the predator as viewed by the prey at the start of its avoidance response and the rate of change of this angle (the looming effect; Schiff 1965) were calculated. It should be noted that these are apparent stimulus thresholds because the motor response must develop at some time after the true threshold is reached.

The rate of change of the visual angle at the start of a motor response, the apparent looming threshold (ALT), was calculated as described by Webb (1982a) after Dill (1974a).

$\mathrm{ALT}=\frac{4 U \cdot S_{\mathbf{h}}}{4 \cdot D^{2}+S_{\mathbf{h}}{ }^{2}} \mathrm{rad} \cdot \mathrm{s}^{-1}$

where $U=$ speed of predator at the time of a prey motor response, $S_{\mathbf{h}}=$ the mean of maximum depth and width, $D=$ distance from the prey to the location of the maximum depth and width of the predator at the instant of a prey motor response.

\section{Results}

Observations concentrate on the prey. Except for a brief outline of predator swimming behavior, details of their strike tactics will be considered elsewhere.

\section{Prey Swimming Behavior}

The behavior of the minnows after introduction to the observation arena was the same as that previously described in the presence of musky (Webb and Skadsen 1980). The minnows swam throughout the arena, ignoring stationary predators. Routine swimming activity by the prey consisted of swimming periods alternating with stationary periods.

\section{Predator Swimming Behavior}

Predators usually remained in one corner of the arena, holding station by means of low frequency, small amplitude median and paired fin movements. They oriented to and attacked prey from 0.5 to $10 \mathrm{~min}$ after the prey were introduced to the arena; observations were terminated if predators ignored prey for more than $10 \mathrm{~min}$, which was not uncommon for rock bass.

Tiger musky struck ay prey using acceleration lunges (Webb and Skadsen 1980). Trout attacked using normal periodic swimming movements characteristic of steady speed swimming. Bass approached prey in a manner similar to trout, except that pectoral propulsion was often used at the start of a strike. Rock bass used caudal swimming and also made greater use of sustained pectoral swimming, often synchronously with caudal propulsion.

Minnows responded to 28 to $90 \%$ of strikes by the four predators. No simple relationship was found between absolute size (mean of maximum depth and width) and the proportion of responses (Fig. 2). Similar percentages of minnow responses $(75-90 \%)$ to strikes by trout, bass and rock bass were observed, whereas responses to tiger musky only occurred in $28 \%$ of strikes. A possible caret-shaped relationship is indicated between the percentage of responses and predator size, as was found by Ewert and Rehn (1969) for avoidance reactions of Bufo viridis to discs. However, these data are not directly comparable because the discs moved in circles around the toad so that the threat of impending collision was absent.

All avoidance responses involved a turn directed away from an approaching predator, followed by a period of swimming of variable duration and intensity. Two patterns of prey avoidance maneuver were identified, called here type-1 and type- 2 responses. Kinematically similar turning and swimming maneu- 


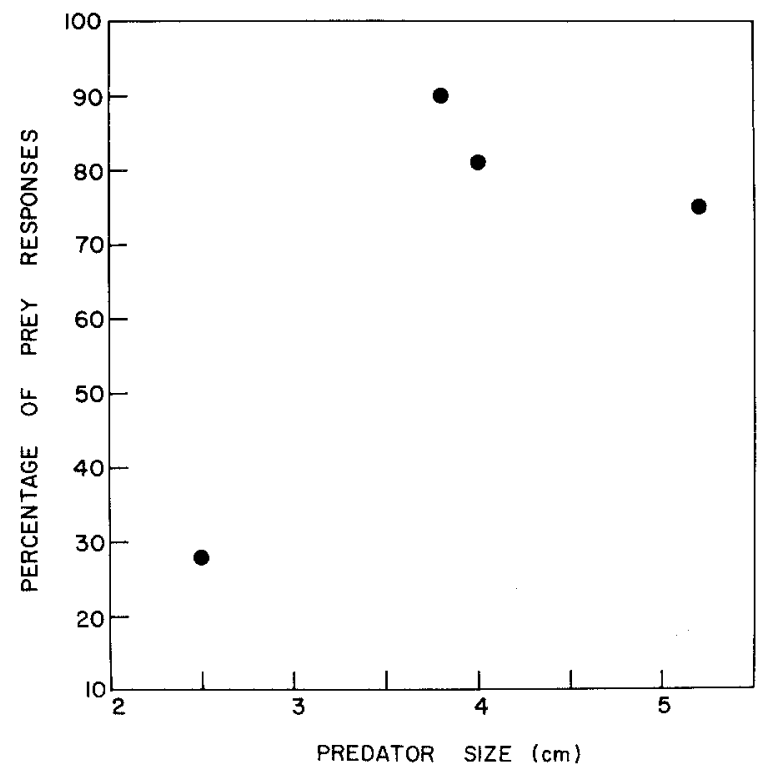

Fig. 2. Relationship between the percentage of avoidance responses of fathead minnow in relation to predator size, calculated as mean of maximum width and depth

vers were seen during routine swimming. These maneuvers were easily differentiated from avoidance responses because the latter were clearly directed away from a predator moving towards the prey.

Type-1 responses were usually made in response to more distant and/or slower predators compared to type-2 responses (Table 2). Type-1 responses were kinematically variable, and of lower intensity with speeds and turning angles of $26-36 \mathrm{~cm} \cdot \mathrm{s}^{-1}$ and $0.99-1.20 \mathrm{rad}$, respectively. Type- 2 responses were stereotyped, high intensity acceleration turns with initial speeds from $61-85 \mathrm{~cm} \cdot \mathrm{s}^{-1}$ and turning angles of 1.4-1.6 rad. Differences in predator speeds, prey reaction distance and initial prey escape speeds were significantly different between the two response patterns to strikes by each predator, but turning angles were not significantly different ( $t$-test; $\alpha=0.05$ ), Type- 1 and -2 responses were seen in both moving and stationary prey, but there were no significant differences in kinematic patterns or escape swimming performance in these situations.

The type and magnitude of the prey response varied with the predator. No prey type-1 responses occurred during strikes by tiger musky. Initial prey speeds of type- 1 and type- 2 responses to strikes by rock bass were 26 and $61 \mathrm{~cm} \cdot \mathrm{s}^{-1}$ respectively. Speeds were similar for the other three species with overall mean values of $35 \mathrm{~cm} \cdot \mathrm{s}^{-1}$ for type-1 responses and $82 \mathrm{~cm} \cdot \mathrm{s}^{-1}$ for type- 2 responses. Values for rock bass were significantly lower than those for the other three predators (Duncans Multiple Range Test: $\alpha=0.05$ ).

Avoidance responses were effective in evading strikes. Responding minnows evaded $72-94 \%$ of strikes by trout, bass and rock bass, and type- 1 responses tended to be more effective than type- 2 responses (Table 3). Tiger musky were more effective in striking prey as only $54 \%$ of responding minnows escaped. Trout, bass and rock bass sometimes chased prey so that 54 to $69 \%$ of responding minnows eventually escaped attacks by the predators.

The various predator swimming patterns resulted in differences in speeds during attacks and hence closure times, calculated from reaction distances and predator speeds in Table 2, would vary. The prey did not respond in any consistent pattern to these expected closure times. In all situations, expected closure times for attacks by trout and bass were comparable, with overall mean values of $244 \mathrm{~ms}$ and $70 \mathrm{~ms}$ for prey type-1 and -2 responses, respectively. Ex-

Table 2. Mean state variable at the time of prey avoidance response of fathead minnow attacked by four species of teleost predators. Data are shown as $\bar{X} \pm 2 \mathrm{SE}$

\begin{tabular}{|c|c|c|c|c|c|c|c|c|c|c|c|}
\hline \multirow[t]{2}{*}{ Predator } & \multirow{2}{*}{$\begin{array}{l}\text { Total } \\
\text { number } \\
\text { of strikes }\end{array}$} & \multirow{2}{*}{$\begin{array}{l}\mathrm{RD} \\
\mathrm{cm}\end{array}$} & \multicolumn{3}{|c|}{ Type- 1 responses } & \multirow{2}{*}{$\begin{array}{l}\text { Number } \\
\text { of } \\
\text { responses }\end{array}$} & \multirow{2}{*}{$\begin{array}{l}\mathrm{RD} \\
\mathrm{cm}\end{array}$} & \multicolumn{3}{|c|}{ Type-2 responses } & \multirow{2}{*}{$\begin{array}{l}\text { Number } \\
\text { of } \\
\text { responses }\end{array}$} \\
\hline & & & $\begin{array}{l}U_{\mathrm{pred}} \\
\mathrm{cm} \cdot \mathrm{s}^{-1}\end{array}$ & $\begin{array}{l}U_{\text {i prey }} \\
\mathrm{cm} \cdot \mathrm{s}^{-1}\end{array}$ & $\begin{array}{l}\theta_{\text {prey }} \\
\text { rad }\end{array}$ & & & $\begin{array}{l}U_{\text {pred }} \\
\mathrm{cm} \cdot \mathrm{s}^{-1}\end{array}$ & $\begin{array}{l}U_{\mathrm{I} \text { prey }} \\
\mathrm{cm} \cdot \mathrm{s}^{-1}\end{array}$ & $\begin{array}{l}\theta_{\text {prey }} \\
\text { rad }\end{array}$ & \\
\hline $\begin{array}{l}\text { Esox } \\
\text { (tiger musky) }\end{array}$ & 46 & - & - & - & - & 0 & $\begin{array}{r}2.5 \\
\pm 1.4\end{array}$ & $\begin{array}{r}93.5 \\
\pm 7.2\end{array}$ & $\begin{array}{r}85.3 \\
\pm 20.8\end{array}$ & $\begin{array}{r}1.54 \\
\pm 0.37\end{array}$ & 13 \\
\hline $\begin{array}{l}\text { Salmo gairdneri } \\
\text { (trout) }\end{array}$ & 48 & $\begin{array}{r}10.6 \\
\pm 3.1\end{array}$ & $\begin{array}{r}37.7 \\
\pm 9.3\end{array}$ & $\begin{array}{r}35.0 \\
\pm 5.2\end{array}$ & $\begin{array}{r}1.06 \\
\pm 0.33\end{array}$ & 18 & $\begin{array}{r}3.7 \\
\pm 1.8\end{array}$ & $\begin{array}{r}51.2 \\
\pm 8.7\end{array}$ & $\begin{array}{r}80.2 \\
\pm 12.2\end{array}$ & $\begin{array}{r}1.41 \\
\pm 0.21\end{array}$ & 25 \\
\hline $\begin{array}{l}\text { Micropterus salmoides } \\
\text { (bass) }\end{array}$ & 67 & $\begin{array}{r}6.9 \\
\pm 1.6\end{array}$ & $\begin{array}{r}32.3 \\
\pm 4.7\end{array}$ & $\begin{array}{r}35.8 \\
\pm 3.8\end{array}$ & $\begin{array}{r}0.99 \\
\pm 0.28\end{array}$ & 22 & $\begin{array}{r}3.6 \\
\pm 1.2\end{array}$ & $\begin{array}{r}52.7 \\
\pm 10.0\end{array}$ & $\begin{array}{r}82.1 \\
\pm 11.0\end{array}$ & $\begin{array}{r}1.41 \\
\pm 0.17\end{array}$ & 32 \\
\hline $\begin{array}{l}\text { Ambloplites rupestris } \\
\text { (rock bass) }\end{array}$ & 51 & $\begin{array}{r}6.1 \\
\pm 1.3\end{array}$ & $\begin{array}{r}12.6 \\
\pm 3.5\end{array}$ & $\begin{array}{r}26.1 \\
\pm 4.1\end{array}$ & $\begin{array}{r}1.20 \\
\pm 0.35\end{array}$ & 21 & $\begin{array}{r}1.2 \\
\pm 3.0\end{array}$ & $\begin{array}{r}47.5 \\
\pm 12.4\end{array}$ & $\begin{array}{r}61.0 \\
\pm 8.1\end{array}$ & $\begin{array}{r}1.55 \\
\pm 0.24\end{array}$ & 17 \\
\hline
\end{tabular}

$\mathrm{RD}=$ reaction distance; $U_{\text {pred }}=$ predator speed at the time of the prey response; $U_{\mathrm{i} \text { prey }}=$ mean speed of prey during first complete tail beat of response; $\theta_{\text {prey }}=$ angle of turn of prey response after first complete tail beat of response 
Table 3. Effectiveness of minnow avoidance responses in eluding and escaping attacks by four species of predators

\begin{tabular}{llll}
\hline $\begin{array}{l}\text { Predator } \\
\text { species }\end{array}$ & \multicolumn{2}{l}{$\begin{array}{l}\text { \% responding } \\
\text { eluding strike }\end{array}$} & $\begin{array}{l}\text { Total \% } \\
\text { responding } \\
\text { prey }\end{array}$ \\
\cline { 2 - 3 } & $\begin{array}{l}\text { Type-1 } \\
\text { responses }\end{array}$ & $\begin{array}{l}\text { Type-2 } \\
\text { responses }\end{array}$ & $\begin{array}{l}\text { escaping } \\
\text { Esox }\end{array}$ \\
$\begin{array}{l}\text { (tiger musky) } \\
\begin{array}{l}\text { Salmo gairdneri } \\
\text { (trout) }\end{array}\end{array}$ & - & 54 & 54 \\
$\begin{array}{l}\text { Micropterus dolomieu } \\
\text { (rock bass) }\end{array}$ & 88 & 76 & - \\
$\begin{array}{l}\text { Ambloplites rupestris } \\
\text { (bass) }\end{array}$ & 86 & 89 & 63 \\
\hline
\end{tabular}

pected closure times were $484 \mathrm{~ms}$ for type- 1 responses to attacks by rock bass, but $25 \mathrm{~ms}$ for type- 2 responses, comparable to that for type- 2 responses to tiger musky. This pattern of closure times is unrelated to patterns for other parameters of strikes and responses, such as reaction distance, predator speeds, prey response intensity or escape success. Therefore it is clear that differences in performance, and hence closure times, cannot explain differences in catch success of predators, as anticipated from limited observations on other predators (Nyberg 1971; Webb and Skadsen 1980). Instead, other factors influencing stimulus reponse thresholds are implicated.

\section{Response Stimuli}

Reaction distance, visual angle, and the rate of change of that angle (looming effect) are common characteristics of stimuli eliciting avoidance maneuvers (see review by Ewert 1980). Before describing these results, the data treatment must be described.

Minnows responded in two ways to strikes by predators or failed to initiate a response. Of the two major responses, type-2 responses were high intensity maneuvers to immediate threat. Failures to respond to a strike always resulted in the predator contacting the prey, so that the predator threat was large. Therefore, non-responding prey would have been expected to show type-2 responses to the immediate threat. The absence of responses is probably attributable to variation in response thresholds and/or latencies which together result in some prey failing to start a motor response in time to elude a strike. It is therefore believed that data on presumed threatening stimulus characteristics are singly censored for type- 2 avoidance responses (Webb, 1982a); i.e. observations

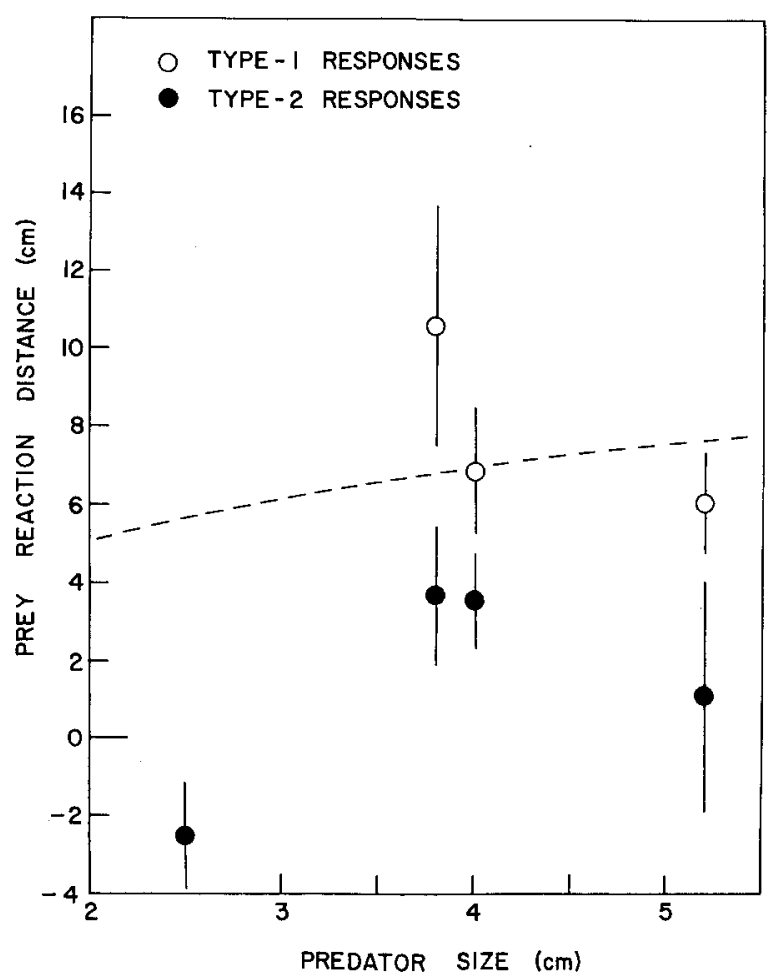

Fig. 3. Reaction distances for fathead minnow avoidance responses shown in relation to predator size. Dotted line was calculated from Eq. 1 in Dill (1973) for hypothetical predators moving at $20 \mathrm{~cm} \cdot \mathrm{s}^{-1}$ against prey with a response threshold of $1.5 \mathrm{rad} \cdot \mathrm{s}^{-1}$. Vertical bars show $\pm 2 \mathrm{SE}$

from $x_{\mathrm{o}}$ to $x_{\mathrm{n}}$ were obtained from $\mathrm{n}$ responding prey from a total sample size of $N$ (responding plus nonresponding prey). Values for $x_{\mathrm{n}}$ to $x_{\mathrm{N}}$ are unknown for prey failing to elicit a motor response in time to elude a strike. Maximum likelihood means and variance were calculated for such singly censored samples using the methods described by Cohen (1961). In some cases, data transformation (logarithmic) was found to minimize the variance. Data for type- 1 responses was assumed to be uncensored.

Results for prey reaction distance at the instant of a prey avoidance response are shown as a function of mean predator cross-sectional size in Fig. 3. For type-1 responses to strikes by trout, bass and rock bass, prey reaction distance decreased with increasing predator size. The same trend was found for maximum likelihood mean reaction distances in type-2 responses for these three predators. The maximum likelihood mean reaction distance for type- 2 responses to strikes by tiger musky was negative reflecting the small number of responses and small reaction distances of responding minnows (Table 2). This best estimate of mean reaction distances of minnows to tiger musky was very much lower than would be expected from the results for other predators. 


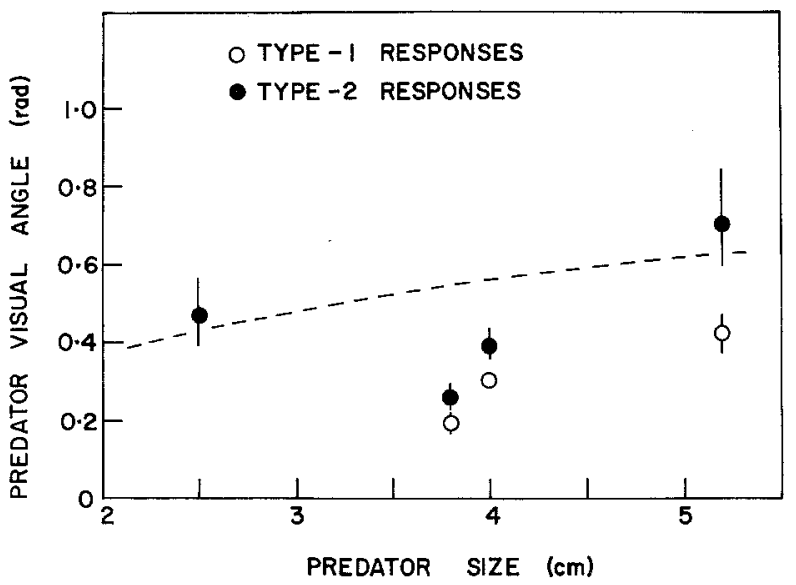

Fig. 4. Relationship between visual angle of an approaching predator at the start of a prey's avoidance response and predator size. Dotted line is based on Dill (1973) using the same parameters as in Fig. 3. Veritical bars: $\pm 2 \mathrm{SE}$

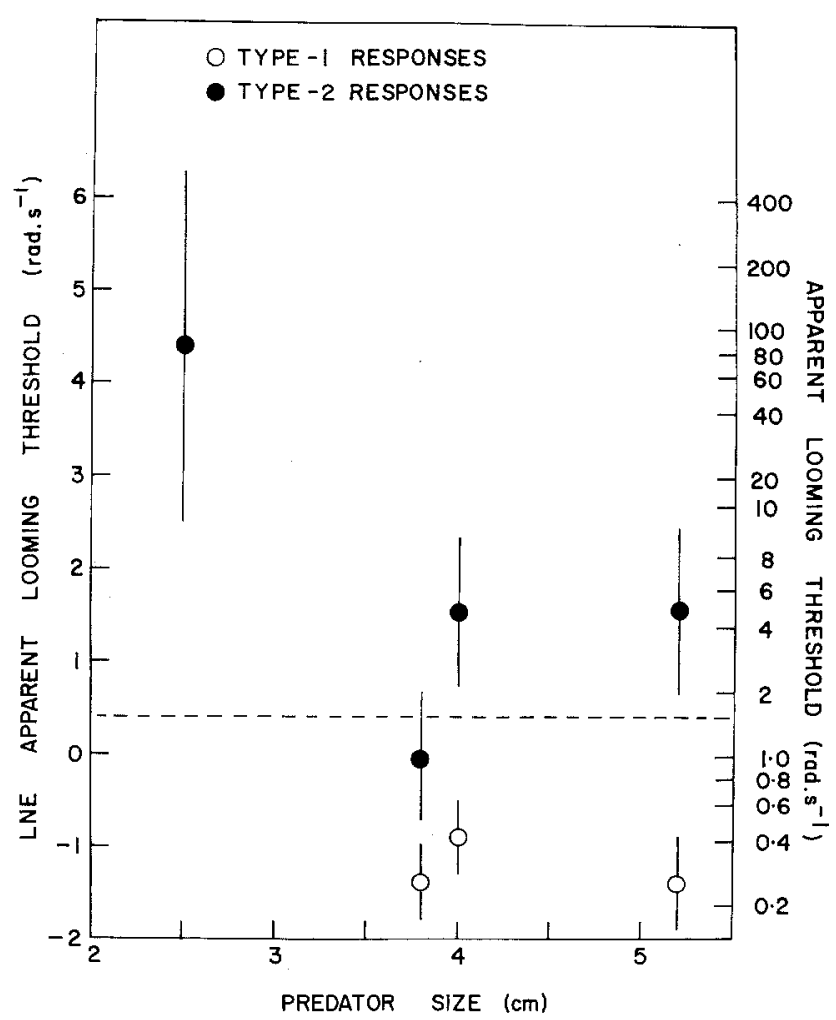

Fig. 5. Relationship between apparent looming threshold, and predator size. Dotted line is the value used by Dill (1973) in modelling predator-prey interactions. It is based on data in Dill (1974a) for naive zebra danios. Vertical bars: $\pm 2 \mathrm{SE}$

The general trend in the relationship between prey reaction distance and predator size was opposite to that found in fish by Dill (1974a) and Hurley and Hartline (1974). However, the predator visual angle, as viewed by the prey at the start of its motor re- sponse, increased with increasing predator size for trout, bass and rock bass (Fig. 4). This is consistent with observations by Dill $(1974 \mathrm{a}, \mathrm{b})$ and Hurley and Hartline (1974). However, tiger musky visual angles were larger than expected on the basis of the observations on the other predators.

The various studies on fish and other animals (Dill 1973, 1974 a, b; Curio 1976; Ewert 1980) have emphasized the importance of motion in eliciting avoidance responses. This is taken into account by the rate of change of the visual angle, calculated here as the apparent looming threshold (ALT). ALTs for type-1 responses to strikes by trout, bass and rock bass (Fig. 5) were not significantly different ( $t$-test; $\alpha=0.05$ ). ALTs for type- 2 responses to strikes by bass and rock bass were also comparable, and although that for trout was of the same order, it was significantly lower. Data for trout, bass and rock bass were similar to the value obtained by Dill (1974a) for zebra danios, Brachydanio rerio in response to approaching discs and to attacks by largemouth bass, Micropterus salmoides. ALTs in response to tiger musky strikes were 15-80 times greater than those of type-2 responses to the other three predators tested here.

\section{Discussion}

The present experiments show that fathead minnows respond in two different ways to attack by predators. Thus low intensity responses were observed with lower intensity stimuli (type-1 responses) and higher intensity responses were observed with a more immediate predator hazard (type- 2 responses). The experiments could not anticipate these two response categories, and therefore cannot explain the basis for them. It is possible that the two response patterns reflect errors in the prey's decision making process, such that type-1 responses represent error decisions to avoid a predator when the threat is low (Treisman 1975).

In addition, the nature and characteristics of the minnow responses varied with the four predators used in the experiments. First, no type-1 responses were observed in response to strikes by tiger musky. Second, response percentages, prey reaction distance, the predator visual angle threshold, and apparent looming threshold varied regularly among trout, bass and rock bass in relation to the size of the predator's cross-section. However, responses to tiger musky were always distinct, the prey being very much less responsive to strikes by this predator compared to the other three species. Third, the intensity of the minnow response to strikes by rock bass was lower than to tiger musky, bass and rock bass. 
These various minnow responses must be due to differences among the predators. Ewert (1980) has recently synthesized much of the information on prey and predator detection, and shown that responses are usually made to the configuration, size and motion of a threatening object. These characteristics may be important individually or in concert.

Size alone cannot explain the various minnow responses to attack. For example, Figs. 2 and 3 show that while the number of responses and prey reaction distances appear to be related to predator cross-sectional size for trout, bass and rock bass, responses to tiger musky are distinct and diverge markedly from expectations based on observations for the other three predators. The same pattern is seen for the visual angle subtended by the predator silhouettes at the instant of a prey response (Fig. 4).

However, some of the observations appear to conflict with results obtained on fish with model and real predators (Dill 1974a, b; Hurley and Hartline 1974). But these experiments also showed that predator speed was an equally important contributor to the stimulus initiating avoidance responses. Dill $(1974 \mathrm{a}, \mathrm{b})$ showed that speed, size and distance from the prey could be combined in a single measure as the rate of change of the visual angle subtended by a putative predator (the looming effect), calculated here as the apparent looming threshold (ALT) at the start of the prey motor response. Using zebra danios, Dill $(1974 \mathrm{a}, \mathrm{b})$ showed that the looming threshold was independent of the size and speed of an approaching, threatening, object. Indeed, Dill (1973) used this common stimulus threshold to calculate reaction distances for predators of different sizes and moving at variable speeds in a model of fish predator-prey interactions.

When predator motion and size are taken into account in the calculation of ALTs, the prey response remains distinct for tiger musky. However, this measure of predator stimulus intensity gives similar results for trout, bass and rock bass. In addition, ALT values for type- 2 responses to strikes by these three predators are comparable to the response threshold obtained by Dill $(1973,1974$ a) for naive zebra danios avoiding largemouth bass and models. Therefore, the ALTs emphasize the distinctive nature of the minnow response to tiger musky compared to other predators.

Since size and motion cannot explain the response differences in minnows to various predators, configurational differences among the predator species must be important in affecting prey responses. Karplus and Algom (1981) have presented similar arguments for the recognition of predators versus non-predator species by reef fishes. The present observations suggest configurational effects may also be important within these functional groups.

In terms of configuration, trout, bass and rock bass possess a common characteristic distinct from tiger musky. The former three species are all laterally flattened such that the cross-sectional profile is elliptical or lenticular, with the apex accentuated by the location of the dorsal fin. In contrast, tiger musky have a rounded cross-section and the dorsal fin is inserted posteriorly.

The ability of animals to recognize and respond to configurational features of objects is well known. In fish, it has been shown that several species respond more strongly to figures containing apices compared to other figures (see reviews by Sutherland 1968; Northmore et al. 1978). Sutherland (1968) describes 'feature detectors' in fish for the discrimination of apical acute angles in figures, such as occur in the cross-sections of fish like trout, bass and rock bass. Trevarthen (1968) describes typical visuomotor integration pathways where such feature detectors and defensive maneuvers could be coupled. Ewert and Rehn (1969) have shown that avoidance responses of toads vary with the ellipticity of objects, such that flight activity is lower with more elliptical shapes. However, the stimulus to toads was presented on a rotating background without threat of impending collision with the subjects, so that the response pattern of toads and that implied for the minnows may be fortuitous.

These arguments suggest that the configuration of tiger musky is important in reducing prey response sensitivity. This explanation has some attraction because it might explain an apparent sub-optimal locomotor body form for lunging esocid predators which otherwise appears inconsistent with their predation habits (Nursall 1973; Neill and Cullen 1974; Webb and Skadsen 1980). The body form is sub-optimal for acceleration lunges because it lacks an anterior median fin such that energy is wasted as lateral recoil of the anterior of the body or by its control using muscles (see Blight 1977; Lighthill 1977; Webb 1978).

However, the present observations indicate that further factors in addition to configuration also influence prey responses. For example, response intensity to rock bass strikes was lower than that for the other three predators. In this case, the configuration presented by greater use of the pectoral fins may imply lower speeds and lower risks to the prey. In addition, strike motions were different among all four predators, and this could influence prey responses.

In summary, these experiments show a variable response of a forage fish species to different teleost predators. The results suggest predator configura- 
tional differences may be an important stimulus component influencing response variations. However, because real predators were used, each with a large suite of unquantified behavioral characteristics, interpretation of the results cannot be fully conclusive. Nevertheless, the appropriate boundaries are clearly illustrated for the design of definitive experiments with models to test the hypotheses developed by this work on natural predators.

Acknowledgements. This work was supported by a National Science Foundation grant PCM-800-6469. Tiger musky were provided by the Michigan Department of Natural Resources. I am indebted to Drs. L.M. Dill, R.C. Eaton and J.P. Ewert and two anonymous reviewers for their suggestions.

\section{References}

Blight AR (1977) The muscular control of vertebrate swimming movements. Biol Rev 52:181-218

Cohen AC (1961) Tables for maximum likelihood estimates: singly truncated and singly censored samples. Technometrics $3: 535-541$

Curio E (1976) The ethology of predation. Springer Berlin Heidelberg New York

Dill LM (1973) An avoidance learning submodel for a general predation model. Oecologia 13:291-312

Dill LM (1974a) The escape response of the zebra danio (Brachydanio rerio). I. The stimulus for escape. Anim Behav 22:711-722

Dill LM (1974b) The escape response of the zebra danio (Brachydanio rerio). II. The effects of experience. Anim Behav $22: 723-730$

Ewert JP (1980) Neuro-ethology. Springer, Berlin Heidelberg New York

Ewert JP, Rehn B (1969) Quantitative Analyse der Reiz-ReaktionsBeziehungen bei visuellem Auslösen des Fluchtverhaltens der Wechselkröte (Bufo viridis Laur.). Behaviour 35:212-234

Hurley AC, Hartline PH (1974) Escape responses in damselfish Chromis cyanea (Pisces: Pomacentridae): A quantitative study. Anim Behav 22:430-437

Karplus I, Algom D (1981) Visual clues for predator face recognition by reef fishes. Z Tierpsychol $55: 343-364$
Lighthill MJ (1977) Mathematical theories of fish swimming. In: Stecle JH (ed) Fisheries mathematics. Academic Press, New York, pp 131-144

Major PF (1978) Predator-prey interactions in two schooling fishes, Caranx ignobilis and Stolephorus purpureus. Anim Behav 26:760-777

Neill SRSJ, Cullen JM (1974) Experiments on whether schooling by their prey affects the hunting behavior of cephalopods and fish predators. J Zool 172:549-569

Northmore D, Volkmann FC, Yager D (1978) Vision of fishes: color and pattern. In: Mostofksy DI (ed) The behavior of fish and other aquatic animals. Academic Press, New York, pp 76-136

Nursall JR (1973) Some behavioral interactions of spottail shiners (Notropis hudsonius), yellow perch (Perca flavescens), and Northern pike (Esox lucius). J Fish Res Board Can 30: 1161-1178

Nyberg DW (1971) Prey capture in the largemouth bass. Am Midl Nat $86: 128-144$

Schiff W (1965) Perception of impending collision. Psychol Monogr $79: 1-26$

Sutherland NS (1968) Shape discrimination in goldfish. In: Ingle D (ed) The central nervous system and fish behavior. Univ Chicago Press, Chicago, pp 35-50

Treisman M (1975) Predation and the evolution of gregariousness. II. An economic model for predator-prey interaction. Anim Behav 23:801-825

Trevarthen C (1968) Vision in fishes: The origins of the visual frame for action in vertebrates. In: Ingle D (ed) The central nervous system and fish behavior, Univ Chicago Press, Chicago pp 61-94

Webb PW (1977) Effects of median-fin amputation on fast-start performance of rainbow trout (Salmo gairdneri). 68:123-135

Webb PW (1978) Fast-start performance and body form in seven species of teleost fish. J Exp Biol 74:211-226

Webb PW (1982a) Responses of Northern anchovy, Engraulis mordax, larvae to predation by a biting planktivore, Amphiprion percula. Fish Bull 79:727-735

Webb PW (1982b) Locomotor patterns in the evolution of actinopterygian fishes. Am Zool (in press)

Webb PW, Skadsen JM (1980) Strike tactis of Esox. Can J Zool $58: 1462-1469$

Weihs D (1972) A hydrodynamical analysis of fish turning maneuvers. Proc R Soc Lond [Biol] 182:59-72

Weihs D (1973) The mechanism of rapid starting of slender fish. Biorheology 10:343-350 